\title{
CORRIGENDUM
}

\section{Modeling psychiatric disorders: from genomic findings to cellular phenotypes}

A Falk, VM Heine, AJ Harwood, PF Sullivan, M Peitz, O Brüstle, S Shen, Y-M Sun, JC Glover, D Posthuma and S Djurovic

Molecular Psychiatry (2016) 21, 1321; doi:10.1038/mp.2016.100; published online 21 June 2016

Correction to: Molecular Psychiatry advance online publication, 31 May 2016; doi:10.1038/mp.2016.89

Following publication of this paper, the authors noticed that affiliation 13 and the corresponding author's address were presented incorrectly. The correct affiliation and address appear below:
${ }^{13}$ Department of Medical Genetics, Oslo University Hospital, Oslo, Norway.

Correspondence: Professor Dr S Djurovic, Department of Medical Genetics, Oslo University Hospital, Kirkeveien 166, PO Box 4956 Nydalen, Oslo 0424, Norway. 